\begin{tabular}{|c|l|}
\hline Title & A ssessment of river water qual ity during snowmelt and base flow periods in two catchment areas with different land use \\
\hline Author(s) & Woli, Krishna Prasad; Hay akawa, A tsushi; Kuramochi, Kanta; Hatano, Ryusuke \\
\hline Citation & $\begin{array}{l}\text { Environmental Monitoring and A ssessment, 137(1-3), 251-260 } \\
\text { https://doi.org/10.1007/310661-007-9757-4 }\end{array}$ \\
\hline Issue Date & 2008 02 \\
\hline Doc URL & http://hdl.handle.net/2115/33858 \\
\hline Rights & The original publication is available at www.springerlink.com \\
\hline Type & article (author version) \\
\hline File Information & Woli.pdf \\
\hline
\end{tabular}

Instructions for use 


\title{
ASSESSMENT OF RIVER WATER QUALITY DURING SNOWMELT AND BASE FLOW PERIODS IN TWO CATCHMENT AREAS WITH DIFFERENT LAND USE
}

\begin{abstract}
River water quality was evaluated with respect to eutrophication and land use during spring snowmelt and summer base flow periods in Abashiri (mixed cropland-livestock farming) and Okoppe (grassland-based dairy cattle farming), eastern Hokkaido, Japan. Water from rivers and tributaries was sampled during snowmelt and summer base flow periods in 2005, and river flow was measured. Total $\mathrm{N}(\mathrm{TN}), \mathrm{NO}_{3}-\mathrm{N}$, and Si concentrations were determined using standard methods. Total catchment and upland areas for each sampling site were determined with ArcGIS hydrology modeling software and 1:25 000-scale digital topographic maps. Specific discharge was significantly higher during snowmelt than during base flow. In both areas, TN concentrations increased, whereas Si concentrations decreased, with increased specific discharge, and were significantly higher during snowmelt. The Si:TN mole ratio decreased to below or close to the threshold value for eutrophication (2.7) in one-third of sites during snowmelt. River $\mathrm{NO}_{3}-\mathrm{N}$ concentrations during base flow were significantly and positively correlated with the proportion of upland fields in the catchment in both the Abashiri ( $r=0.88, P<0.001)$ and Okoppe $(r=0.43, P<0.01)$ areas. However, the regression slope, defined as the impact factor (IF) of water quality, was much higher in Abashiri (0.025) than in Okoppe (0.0094). The correlations were also significantly positive during snowmelt in both areas, but IF was four to eight times higher during snowmelt than during base flow. Higher discharge of $\mathrm{N}$ from upland fields and grasslands during snowmelt and the resulting eutrophication in estuaries suggest that nutrient discharge during snowmelt should be taken into account when assessing and monitoring the annual loss of nutrients from agricultural fields.
\end{abstract}

Keywords: eutrophication; impact factor; land use; mole ratio; nitrogen; phosphorus; silica; spring snowmelt; summer base flow 


\section{Introduction}

Runoff from agricultural land is a major cause of non-point source pollution (Daniel et al., 1998), and eutrophication has been identified as a resulting critical problem in surface waters (Artola et al., 1995; Stapleton et al., 2000; Camargo et al., 2005). This anthropogenic disturbance results from activities that enhance $\mathrm{N}$ cycling in the environment: production and application of fertilizers, discharge of human waste, animal production, and combustion of fossil fuels (Nixon, 1995). These activities mobilize $\mathrm{N}$ and $\mathrm{P}$ and accelerate the fluxes of these elements to coastal waters. Fertilization of coastal ecosystems is now a serious environmental problem, because it stimulates plant growth and disrupts the balance between the production and metabolism of organic matter in the coastal zone (Cloern, 2001). There is increasing concern that the ratio of $\mathrm{Si}$ to $\mathrm{N}$ (or $\mathrm{P}$ ) is decreasing, potentially limiting diatom productivity, because human activities have selectively enhanced the loading of $\mathrm{N}$ and $\mathrm{P}$, but not that of Si, to coastal waters (Cloern, 2001). Particularly during snowmelt periods, phytoplankton increase in coastal seas; siliceous species increase first, and then nonsiliceous species take their place when the mole ratio of Si to $\mathrm{N}$ in water bodies falls below 2.7, considered the threshold value for eutrophication (Kudo and Matsunaga, 1999). The mole ratio of Si to TN concentrations in river water is a useful predictor of eutrophication in coastal seas during the snowmelt season. The Si:TN mole ratio in river water has been reported to be less than the threshold value in $10 \%-40 \%$ of rivers in those regions of southern and central Hokkaido that are favorable to animal husbandry or dairy farming (Nagumo and Hatano, 2001). Hatano et al. (2005) also reported that the Si:TN mole ratio in river water in Hokkaido falls considerably below the threshold value during the snowmelt season, and that $90 \%$ of the $\mathrm{N}$ loading occurs during rainfall and spring snowmelt events. 
Magnitude of nutrient leaching from agricultural soils is dependant on land use in the drainage basins (Sileika et al., 2005). A positive relationship has been reported between the proportion of farmland in drainage basins and the $\mathrm{NO}_{3}-\mathrm{N}$ concentration in river water (Smart et al., 1985; Neill, 1989; Tabuchi et al., 1995; Jordan et al., 1997; Cronan et al., 1999; McFarland and Hauck 1999; Woli et al., 2002; Buck et al., 2004; Woli et al., 2004; Hayakawa et al., 2006). Woli et al. (2002) found that the upland field proportion is significantly positively correlated with the $\mathrm{NO}_{3}-\mathrm{N}$ concentration during summer base flow, and that the regression slope of the relationship varies with land use. As the regression slope appeared to be an index of the impact of land use on river water quality, Woli et al. (2002) defined it as the impact factor (IF). However, very few water quality studies have been carried out during the snowmelt season, so the impact intensity of farmland on river water quality during snowmelt events is still unclear. Moreover, river $\mathrm{N}$ concentrations are generally lower in grassland-based livestock farming areas than in intensive agricultural areas (Tabuchi et al., 1995). Therefore, this study was carried out to evaluate and compare river water quality in relation to eutrophication and land use during spring snowmelt and summer base flow periods between a grassland-based dairy cattle farming area and a mixed cropland-livestock farming area.

\section{Materials and Methods}

\section{STUDY AREA}

Two catchment areas with different land use in eastern Hokkaido, Japan, were selected for this study (Fig. 1). The Abashiri area $\left(43^{\circ} 46^{\prime} \mathrm{N}, 144^{\circ} 11^{\prime} \mathrm{E}\right)$, which comprises Abashiri and Memanbetsu cities and Bihoro and Tsubetsu towns, is characterized by mixed cropland-livestock husbandry. The Okoppe area $\left(44^{\circ} 21^{\prime} \mathrm{N}, 143^{\circ} 2^{\prime} \mathrm{E}\right)$, which comprises 
Okoppe and Nishi Okoppe towns, is dominated by dairy cattle farming. Both catchment areas drain into the Okhotsk Sea. Characteristics of each area are listed in Table 1. About $81 \%$ of the total area in Abashiri is occupied by common upland fields cultivated with sugar beet (Beta vulgaris L.), wheat (Triticum aestivum L.), or potato (Solanum tuberosum L.). In contrast, $98 \%$ of the total agricultural area in Okoppe is occupied by grasslands. Livestock in Abashiri consists of pigs, and beef and dairy cattle, and the livestock density is 1.0 animal unit per hectare $\left(\mathrm{au} \mathrm{ha}^{-1}\right)$, whereas in Okoppe the density of livestock (mainly dairy cattle) is $1.9 \mathrm{au} \mathrm{ha}^{-1}$ (Table 1 ). The major soil types are volcanic ash-derived Andosols and Brown Forest Soils in Abashiri, and in Okoppe, Brown Forest Soils and Brown Forest Lowland Soils. The climate in both areas is temperate: annual mean temperature is $6.2{ }^{\circ} \mathrm{C}$ and annual mean precipitation $802 \mathrm{~mm}$ in Abashiri (http://www.city.abashiri.hokkaido.jp/), and they are $6.5^{\circ} \mathrm{C}$, and $1073 \mathrm{~mm}$ in Okoppe (http://www.vill.nishiokoppe.hokkaido.jp/).

\section{WATER SAMPLING AND CHEMICAL ANALYSIS}

In both catchment areas, water samples were collected from the main river channels and from tributaries to these rivers. In Abashiri, a total of 63 sites were sampled during both spring snowmelt and summer base flow periods, and in Okoppe, 46 and 49 sites were sampled during snowmelt and base flow, respectively (Fig. 2). Water samples were collected manually once in the snowmelt season (9-15 April) and once during base flow (12-16 August) in 2005, and at the same time river velocity was also measured with a flow velocity meter (TK-105; Toho Dentan, Tokyo) at each sampling point. River discharge was calculated by multiplying the river cross-sectional area by flow velocity at $60 \%$ depth at various points along a transect across the main river and its tributaries. The river discharge per unit drainage area, that is, specific discharge, was later 
calculated by dividing discharge by the catchment area above the sampling site. After sampling, water samples were stored on ice and transported to the laboratory. At the laboratory, a part of the samples were filtered through prerinsed $0.2-\mu \mathrm{m}$ filter paper, and the $\mathrm{NO}_{3}-\mathrm{N}$ concentration was determined with ion chromatography (QIC Analyzer; Dionex, Sunnyvale, CA), and the Si concentration was determined colorimetrically by the molybdenum blue method. The TN concentration was determined in unfiltered samples by alkaline persulfate digestion using the $\mathrm{HCl}$-acidified UV detection method (Japanese Standard Association, 1993).

\section{LAND USE ANALYSIS}

The size of the catchment above each sampling site in both areas was determined using ArcGIS 9.0-hydrology modeling software (ESRI Press, New York). The upland fields were delineated on digital topographic maps of 1:25 000 scale, and the total area and the area of upland fields in all catchments were calculated using a digital elevation model. The drainage basin of lower reach streams was calculated by including the drainage basins of all upper streams and tributaries that flow into it. Common upland fields, including grasslands but excluding lowland paddy fields, are referred to as "upland fields" in this study. The proportion of upland fields was estimated as the percentage of upland fields relative to the total area of the subcatchment above each sampling point.

\section{STATISTICAL ANALYSIS}

Simple linear regression (Esumi Co. Ltd., Tokyo, Japan) was applied to evaluate the relationship between the proportion of upland fields in each catchment and the $\mathrm{NO}_{3}-\mathrm{N}$ concentration in the river water. The seasonal and spatial variations in element concentrations, Si:TN mole ratios, and specific discharge were compared by using 
analysis of variance. For this study, effects with probabilities of $p<0.05$ were assumed to be significant. Regression slopes of the relationship between upland proportion and river nitrate concentration were compared by using Excel Tahenroukaiseki version 4.0 for windows (in Japanese).

\section{Results}

SPATIAL AND TEMPORAL VARIATION IN SPECIFIC DISCHARGE AND MINERAL CONCENTRATIONS

River discharge per unit drainage area, that is, specific discharge, and the concentrations of $\mathrm{Si}$ and $\mathrm{TN}$ in river water samples during the spring snowmelt and summer base flow periods in the Abashiri and Okoppe areas are shown in Fig. 3, and the results are compared between the areas and the periods by using ANOVA (Table 2). The mean specific discharge was significantly $(P<0.001)$ lower in Abashiri than in Okoppe during snowmelt. However, there was no significant difference in specific discharge during base flow. The mean concentrations of $\mathrm{Si}, \mathrm{TN}$, and $\mathrm{NO}_{3}-\mathrm{N}$ were significantly higher in Abashiri than in Okoppe. The mean specific discharge was significantly higher during snowmelt than during base flow in both Abashiri and Okoppe $(P<0.001)$. The mean concentrations of TN during snowmelt were also significantly higher $(P<0.001)$ than during base flow in both Abashiri and Okoppe. On the other hand, the mean concentration of Si was significantly lower during snowmelt than during base flow in both catchment areas $(P<0.001)$. In Abashiri, some sites had remarkably high TN concentrations, reaching a maximum of $26 \mathrm{mg} \mathrm{L}^{-1}$, during snowmelt, while in Okoppe concentrations were less than $3 \mathrm{mg} \mathrm{L}^{-1}$, even when discharge per unit drainage area was significantly higher (Fig. 3). 


\section{MOLE RATIO OF Si TO TN CONCENTRATIONS}

The distribution of Si:TN mole ratios between snowmelt and base flow periods in Abashiri and Okoppe are illustrated in Figs. 4 and 5, respectively. During base flow, at more than $96 \%$ of the sampling sites in both catchment areas, the mole ratio was above the threshold value for eutrophication. However, the ratio decreased during snowmelt, when the number of sites with the ratio below the threshold value increased to more than one-third of the total sites in the two catchment areas. The mean Si:TN mole ratios were significantly lower $(P<0.001 ; t$ test) during snowmelt than during base flow in both catchment areas (Table 2). Most sites with Si:TN below the threshold value were located in the lower reaches of rivers and at river mouths (Figs. 4 and 5) and where TN concentrations were comparatively higher.

\section{THE PROPORTIONS OF UPLAND FIELDS AND $\mathrm{NO}_{3}-\mathrm{N}$ CONCENTRATIONS}

In the mixed agricultural Abashiri area, the proportion of upland fields in the catchment above each sampling site ranged from $0 \%$ to $91 \%$, and for about one-third of the total sites, the upland field proportion was more than 20\% (Fig. 6). However, the proportion of upland fields in the grassland-based dairy cattle farming Okoppe area was 0\%-20\%. In both catchment areas, the proportion of upland fields increased from upstream to downstream sampling sites. In Abashiri, the $\mathrm{NO}_{3}-\mathrm{N}$ concentration range was $0.02-3.2$ $\mathrm{mg} \mathrm{L}^{-1}$ during base flow, while it was $0.04-22.2 \mathrm{mg} \mathrm{L}^{-1}$ during snowmelt, and it exceeded the drinking water standard of $10 \mathrm{mg} \mathrm{L}^{-1}$ set by the U.S. Environmental Protection Agency (Spalding and Exner, 1993) at four sites. In contrast, in the Okoppe area, the concentration range was $0.01-0.47$ and $0.05-0.91 \mathrm{mg} \mathrm{L}^{-1}$ during base flow and snowmelt, respectively (Fig. 7). 


\subsection{RELATIONSHIP BETWEEN THE UPLAND FIELD PROPORTION AND THE $\mathrm{NO}_{3}-\mathrm{N}$}

CONCENTRATION

Regression analysis showed that $\mathrm{NO}_{3}-\mathrm{N}$ concentrations in river water during base flow were significantly correlated with the proportion of upland fields in the catchments in both Abashiri ( $r=0.88, P<0.001)$ and Okoppe $(r=0.43, P<0.01)$ (Fig. 7). However, the regression slope for Abashiri (0.0249) was 2.6 times that for Okoppe (0.0094). The $\mathrm{NO}_{3}-\mathrm{N}$ concentration was also significantly positively correlated with the upland field proportion during snowmelt in both Abashiri $(r=0.84, P<0.001)$ and Okoppe $(r=0.79$, $P<0.001)$, and the regression slope for Abashiri was significantly higher (0.1920) than that for Okoppe (0.0354). The regression slopes for base flow and snowmelt differed seasonally $(P<0.01)$ in both Abashiri and Okoppe areas.

\section{Discussions}

The discharge per unit drainage area during snowmelt was significantly higher than that during base flow, and the increase in specific discharge was associated with decreased Si concentrations and increased TN concentrations. This result is consistent with study results for the Kepau River, which flows through a livestock farming area in southern Hokkaido, Japan (Hayakawa et al., 2003; Hatano et al., 2005), where the Si:TN mole ratio frequently dropped below the threshold value, enhancing eutrophication, during the snowmelt season. Winter and spring concentrations of nutrients are generally found to be high in areas of similar climate (Macdonald et al., 1995; Buck et al., 2004). However, Si concentrations relate to soil type, being higher in areas with weathered volcanic-ash soils (Nagumo and Hatano, 2001). Our results showed that Si 
concentrations were significantly higher (Table 2) in rivers flowing through the Abashiri area with its volcanic-ash soils (Andosols) than in the Okoppe area with its Brown Forest Soils. In both areas, Si concentrations were significantly lower, possibly owing to a dilution effect, and TN concentrations increased significantly during the snowmelt season, thus lowering the Si:TN mole ratio, leading to eutrophication in the estuaries at the river mouths.

Nitrate concentrations in river water during both snowmelt and base flow were significantly correlated with the proportion of upland fields in the catchment in both Abashiri and Okoppe areas. Several other studies also found significant positive correlations of river $\mathrm{NO}_{3}-\mathrm{N}$ concentrations with upland field proportions (Tabuchi et al., 1995; Woli et al., 2002, 2004; Hayakawa et al., 2006), with pasture land proportions (Smart et al., 1985; Buck et al., 2004), with the percentage of agricultural cropland (Jordan et al., 1997; Cronan et al., 1999; McFarland and Hauck, 1999), or with the percentage of land area ploughed (Neill, 1989). Woli et al. (2002) reported that the regression slope of the relationship or IF on water quality, varied in accordance with the land use. Woli et al. (2004) compared IF values obtained from seven large catchment areas in Hokkaido, Japan, with data from the Chesapeake Bay watershed (Jordan et al., 1997), Aroostook River basin (Cronan et al., 1999), and Missouri Ozark Plateau Province (Smart et al., 1985) in the United States, and concluded that the largest (0.04) IF values were associated with intensive agriculture or livestock farming, intermediate (0.02-0.04) values with mixed agriculture and livestock farming, and the lowest (0.006-0.02) values with grassland-based dairy cattle or horse farming areas. The results of the present study during base flow are consistent with these previous results, as the IF value was 0.0249 for Abashiri, a mixed cropland-livestock farming area, and 0.0094 for Okoppe, a grassland-based dairy cattle farming area. However, the IF values 
were significantly higher during snowmelt than during base flow in both the Abashiri and Okoppe areas. The higher concentrations of $\mathrm{TN}$ and $\mathrm{NO}_{3}-\mathrm{N}$, and the resulting larger IF values, during the snowmelt season can possibly be attributed to $\mathrm{N}$ accumulated or remaining in soils or remaining from the application of chemical fertilizer and manure during autumn being mobilized by surface runoff or leaching during the snowmelt season. Other studies have also reported that spring floods are significant sources of nutrients in river water (Macdonald et al., 1995; Buck et al., 2004). Cambardella et al. (1999) and Hayashi and Hatano (1999) also reported that most of the nitrate in subsurface drainage water is removed from fields when crops are not present during the winter. Randall and Mulla (2001) recommended that N management in agricultural fields could be improved by applying $\mathrm{N}$ at the correct rate at the optimum time, thus reducing nutrient losses to surface water. Ulén et al. (2004) reported that no manure has been spread during autumn in recent years and that there is a decreasing concentration of TN in Swedish catchments. Therefore, appropriate fertilizer management for summer and autumn crops in Hokkaido, where the winter snow-covered period is long, is apparently crucial for preventing excess nutrient losses to surface runoff during the snowmelt season.

Woli et al. (2004) evaluated how different agricultural activities affect IF values and reported that surplus $\mathrm{N}$ in croplands had a better correlation with IF. They scaled up their evaluation using the regression model, associating IF values with all cities, towns, and villages of Hokkaido, and found that the distribution pattern of predicted IF values was very close to that of the measured $\mathrm{NO}_{3}-\mathrm{N}$ concentrations during the snowmelt season for all major rivers in Hokkaido. They also estimated the $\mathrm{NO}_{3}-\mathrm{N}$ concentration for all sampling sites in Hokkaido by multiplying the predicted IF values by the upland field proportion and found that the prediction underestimated the measured values to 
some extent; the measured values at approximately $7 \%$ of the total sites in Hokkaido were higher than the predicted values. Although they used base flow $\mathrm{NO}_{3}-\mathrm{N}$ concentrations to predict IF values, values measured during snowmelt were used in the comparison (Woli et al., 2004). Thus, their results are consistent with those from this study, which also showed that measured $\mathrm{NO}_{3}-\mathrm{N}$ concentrations, as well as calculated IF values, during the snowmelt season were much higher than those during base flow.

\section{Conclusions}

The results of this study confirmed that the land use pattern in catchments affects river water quality and that a greater proportion of upland fields is associated with higher concentrations of $\mathrm{NO}_{3}-\mathrm{N}$ in river water. The impact intensity of the upland field proportion on river $\mathrm{NO}_{3}-\mathrm{N}$ concentrations varied according to the intensity of agriculture; the river $\mathrm{NO}_{3}-\mathrm{N}$ concentrations were higher in mixed cropland-livestock farming areas than in grassland-based dairy cattle farming area. The higher discharge of $\mathrm{N}$ from uplands and grasslands and the decrease in the Si:TN mole ratio below the threshold value for eutrophication during the snowmelt season suggest that the nutrient discharge during snowmelt events should be taken into account when estimating the annual loss of nutrients from agricultural fields to surface runoff. Maintaining an appropriate proportion of upland fields in a catchment and proper fertilizer management of agricultural fields, especially regarding applications in autumn before the winter snow-covered period, can reduce $\mathrm{N}$ discharge to surface runoff and the resulting eutrophication of estuaries.

\section{Acknowledgments}


This study was partly supported by a Japanese Grant-in-Aid for Science Research from the Ministry of Education, Culture, Sports, Science and Technology (16-04428).

\section{References}

Artola, C.G., Pareja, B.L. and Garcia, P.G.: 1995, 'Impact on hydrology and nutrient movements of developments in river basins draining into reservoirs', Water Res. 29, 601-609.

Buck, O., Niyogi, D.K. and Townsend, C.R.: 2004, 'Scale-dependence of land use effects on water quality of streams in agricultural catchments', Environ. Pollut. 130, 287-299.

Camargo, J.A., Alonso, A. and Puente, M.: 2005, 'Eutrophication downstream from small reservoirs in mountain rivers of Central Spain’, Water Res. 39, 3376-3384.

Cambardella, C.A., Moorman, T.B., Jaynes, D.B., Hatfield, J.L., Parkin, T.B., Simpkins W.W. and Karlen, D.L.: 1999, 'Water quality in Walnut Creek watershed: Nitrate-nitrogen in soils, subsurface drainage water, and shallow groundwater', $J$. Environ. Qual. 28, 25-34.

Cloern, J.E.: 2001, 'Our evolving conceptual model of the coastal eutrophication problem’, Mar. Ecol. Prog. Ser. 210, 223-253.

Cronan, C.S., Piampiano, J.T. and Patterson, H.H.: 1999, 'Influence of land use and hydrology on exports of carbon and nitrogen in a Maine River basin', J. Environ. Qual. 28, 953-961.

Daniel, T.C., Sharpley, A.N. and Lemunyon, J.L.: 1998, 'Agricultural phosphorus and eutrophication. A symposium overview’, J. Environ. Qual. 27, 251-257. 
Hatano, R., Nagumo, T., Hata, H. and Kuramochi, K.: 2005, 'Impact of nitrogen cycling on stream water quality in a basin associated with forest, grassland, and animal husbandry, Hokkaido, Japan’, Ecol. Eng. 24, 509-515.

Hayakawa, A., Nagumo, T., Kuramochi, K. and Hatano, R.: 2003, 'Characteristics of nutrient load in a stream flowing through a livestock farm during spring snowmelt', Soil Sci. Plant Nutr. 49, 301-305.

Hayakawa, A., Shimizu, M., Woli, K.P., Kuramochi, K. and Hatano, R.: 2006, 'Evaluating stream water quality through land use analysis in two grassland catchments: Impact of wetlands on stream nitrogen concentration', J. Environ. Qual. 35, 617-627.

Hayashi, Y. and Hatano, R.: 1999, 'Annual nitrogen leaching to subsurface drainage water from a Clayey Aquic soil cultivated with onions in Hokkaido, Japan', Soil Sci. Plant Nutr. 45, 451-459.

Japanese Standard Association: 1993, 'Testing Methods for Industrial Wastewater, Japan Industrial Standard (JIS) K 0102 45.2; JIS K 0102 46.3.1 (in Japanese).

Jordan, T.E., Correll, D.L. and Weller, D.E.: 1997, 'Effects of agriculture on discharges of nutrients from coastal plain watersheds of Chesapeake Bay’, J. Environ. Qual. 26, 836-848.

Kudo, I. and Matsunaga, K.: 1999, 'Environmental factors affecting the occurrence and production of the spring phytoplankton bloom in Funka Bay, Japan', J. Oceanogr. 55, 505-513.

MacDonald, A.M., Edwards, A.C., Pugh, K.B. and Balls, P.W.: 1995, 'Soluble nitrogen and phosphorus in the river Ythan system, U.K.: Annual and seasonal trends', Water Res. 29, 837-846.

McFarland, A.M.S. and Hauck, L.M.: 1999, 'Relating agricultural land uses to in-stream 
stormwater quality’, J. Environ. Qual. 28, 836-844.

Nagumo, T. and Hatano, R.: 2001, 'Regional characteristics of stream water quality during the snow-melting season in Hokkaido (in Japanese with English summary) ', Jpn. J. Soil Sci. Plant Nutr. 72, 41-48.

Neill, M.: 1989, 'Nitrate concentrations in river waters in the South-East of Ireland and their relationship with agricultural practice', Water Res. 23, 1339-1355.

Nixon, S.W.: 1995, 'Coastal marine eutrophication-A definition, social causes, and future concerns’, Ophelia 41, 199-219.

Nyukantori Editor: 1976, Land application of livestock urine and feces, Hokkaido Kyodo Kumiai Tsuain-sha, Sapporo (in Japanese), pp 372-381.

Randall, G.W. and Mulla, D.J.: 2001, 'Nitrate nitrogen in surface waters as influenced by climatic conditions and agricultural practices’, J. Environ. Qual. 30, 337-344.

Sileika, A.S., Gaigalis, K., Kutra, G. and Smitiene, A.: 2005, 'Factors affecting N and P losses from small catchments (Lithuania)’, Environ. Monit. Assess. 102, 359-374.

Smart, M.M., Jones, J.R. and Sebaugh, J.L.: 1985, 'Stream-watershed relations in the Missouri Ozark Plateau Province', J. Environ. Qual. 14, 77-82.

Spalding, R.F. and Exner, M.E.: 1993, 'Occurrence of nitrate in groundwater-A review', J. Environ. Qual. 22, 392-402.

Stapleton, C.M., Kay, D., Jackson, G.F. and Wyer, M.D.: 2000, 'Estimated inorganic nutrient inputs to the coastal waters of Jersey from catchment and waste water sources’, Water Res. 34, 787-796.

Tabuchi, T., Yoshino, K., Shimura, M., Kuroda, S., Ishikawa, M. and Yamaji, E.: 1995, 'Relation between land use and nitrate concentration of outflow water from watersheds of agricultural and forest areas (in Japanese with English summary) ', Jpn. Soc. Irrigation Drainage Reclamation Eng. 178, 129-135. 
Ulén, B., Carlsson, C. and Lidberg, B.: 2004, 'Recent trends and patterns of nutrient concentrations in small agricultural streams in Sweden’, Environ. Monit. Assess. 98, 307-322.

Woli, K.P., Nagumo, T. and Hatano, R.: 2002, 'Evaluating impact of land use and N budgets on stream water quality in Hokkaido, Japan', Nutr. Cycl. Agroecosyst. 63, 175-184.

Woli, K.P., Nagumo, T., Kuramochi, K. and Hatano, R.: 2004, 'Evaluating river water quality through land use analysis and $\mathrm{N}$ budget approaches in livestock farming areas', Sci. Total Environ. 329, 61-74. 


\section{Figure legends}

Figure 1. Locations of the study areas in eastern Hokkaido, Japan.

Figure 2. River systems and sampling site distributions in the (a) Abashiri and (b) Okoppe areas.

Figure 3. Specific discharge and concentrations of TN and Si in river water during spring snowmelt and summer base flow periods in the (a) Abashiri and (b) Okoppe areas.

Figure 4. Mole ratio of Si:TN at each sampling site in the Abashiri area during (a) spring snowmelt and (b) summer base flow.

Figure 5. Mole ratio of Si:TN at each sampling site in the Okoppe area during (a) spring snowmelt and (b) summer base flow.

Figure 6. Proportions of upland field in subcatchments in the (a) Abashiri and (b) Okoppe areas.

Figure 7. Relationships between proportion of upland fields in catchments and the $\mathrm{NO}_{3}-\mathrm{N}$ concentration in river water for the (a) Abashiri and (b) Okoppe areas.

TABLE I

Area, population, land use, and livestock in the Abashiri and Okoppe areas

\begin{tabular}{lcc}
\hline & Abashiri area & Okoppe area \\
\hline Population & 85596 & 10891 \\
Total area $\left(\mathrm{km}^{2}\right)$ & 1969 & 671 \\
Agricultural land (ha) & 39988 & 7928 \\
$\quad$ Common upland & 32554 & 168 \\
$\quad$ Paddy field & 389 & 0 \\
$\quad$ Grassland & 7041 & 7760 \\
Livestock (head) & & \\
$\quad$ Beef cattle & 16400 & 1620 \\
$\quad$ Dairy cattle & 13990 & 13330 \\
$\quad$ Pig & 76230 & 0 \\
Livestock density $\left(\mathrm{au} \mathrm{ha}^{-1}\right)^{*}$ & 1.0 & 1.9 \\
\hline
\end{tabular}

*1 au is equivalent to one head of dairy or beef cattle or eight pigs, based on The amount of excrement produced (Nyukantori Editor, 1976). 
TABLE II

Specific discharge $\left(\mathrm{m}^{3} \mathrm{~s}^{-1} \mathrm{~km}^{-2}\right)$, concentrations $\left(\mathrm{mg} \mathrm{L}^{-1}\right)$ of $\mathrm{Si}$, TN, and $\mathrm{NO}_{3}-\mathrm{N}$, and $\mathrm{Si}$ :TN mole ratio in river water samples. Values are means $\pm \mathrm{SD}$, and significant $(P<0.05)$ differences are indicated

\begin{tabular}{|c|c|c|c|c|}
\hline Variable & & $\begin{array}{c}\text { Abashiri area } \\
\text { (Mixed cropland-livestock husbandry) }\end{array}$ & $\begin{array}{c}\text { Okoppe area } \\
\text { (Dairy cattle farming) }\end{array}$ & $P$-value \\
\hline $\begin{array}{l}\text { Specific } \\
\text { discharge }\end{array}$ & $\begin{array}{l}\text { Snowmelt } \\
\text { Base flow } \\
P \text {-value }\end{array}$ & $\begin{array}{c}0.023( \pm 0.017) \\
0.010 \stackrel{( \pm 0.005)}{* * *}\end{array}$ & $\begin{array}{c}0.056( \pm 0.023) \\
0.011( \pm 0.006) \\
* * *\end{array}$ & $* * *$ \\
\hline Silica & $\begin{array}{l}\text { Snowmelt } \\
\text { Base flow } \\
P \text {-value }\end{array}$ & $\begin{array}{c}17.88( \pm 3.85) \\
22.10( \pm 6.56) \\
* * *\end{array}$ & $\begin{array}{c}5.86( \pm 0.98) \\
7.70( \pm 2.16) \\
* * *\end{array}$ & $\begin{array}{l}* * * \\
* * *\end{array}$ \\
\hline $\mathrm{TN}$ & $\begin{array}{l}\text { Snowmelt } \\
\text { Base flow } \\
P \text {-value }\end{array}$ & $\begin{array}{c}3.53( \pm 4.58) \\
1.07( \pm 1.13) \\
* * *\end{array}$ & $\begin{array}{c}0.84( \pm 0.34) \\
0.37 \underset{* * *}{( \pm 0.24)} \\
* * *\end{array}$ & $\begin{array}{l}* * * \\
* * *\end{array}$ \\
\hline $\mathrm{NO}_{3}-\mathrm{N}$ & $\begin{array}{l}\text { Snowmelt } \\
\text { Base flow } \\
P \text {-value }\end{array}$ & $\begin{array}{c}2.93( \pm 4.37) \\
0.37( \pm 0.51) \\
* * *\end{array}$ & $\begin{array}{c}0.39( \pm 0.20) \\
0.12( \pm 0.10) \\
* * *\end{array}$ & $\begin{array}{l}* * * \\
* *\end{array}$ \\
\hline $\begin{array}{l}\text { Si:TN mole } \\
\text { ratio }\end{array}$ & $\begin{array}{l}\text { Snowmelt } \\
\text { Base flow } \\
P \text {-value }\end{array}$ & $\begin{array}{c}6.99( \pm 7.38) \\
15.89( \pm 8.20) \\
* * *\end{array}$ & $\begin{array}{c}4.25( \pm 2.70) \\
13.19( \pm 8.0) \\
* * *\end{array}$ & $*$ \\
\hline
\end{tabular}




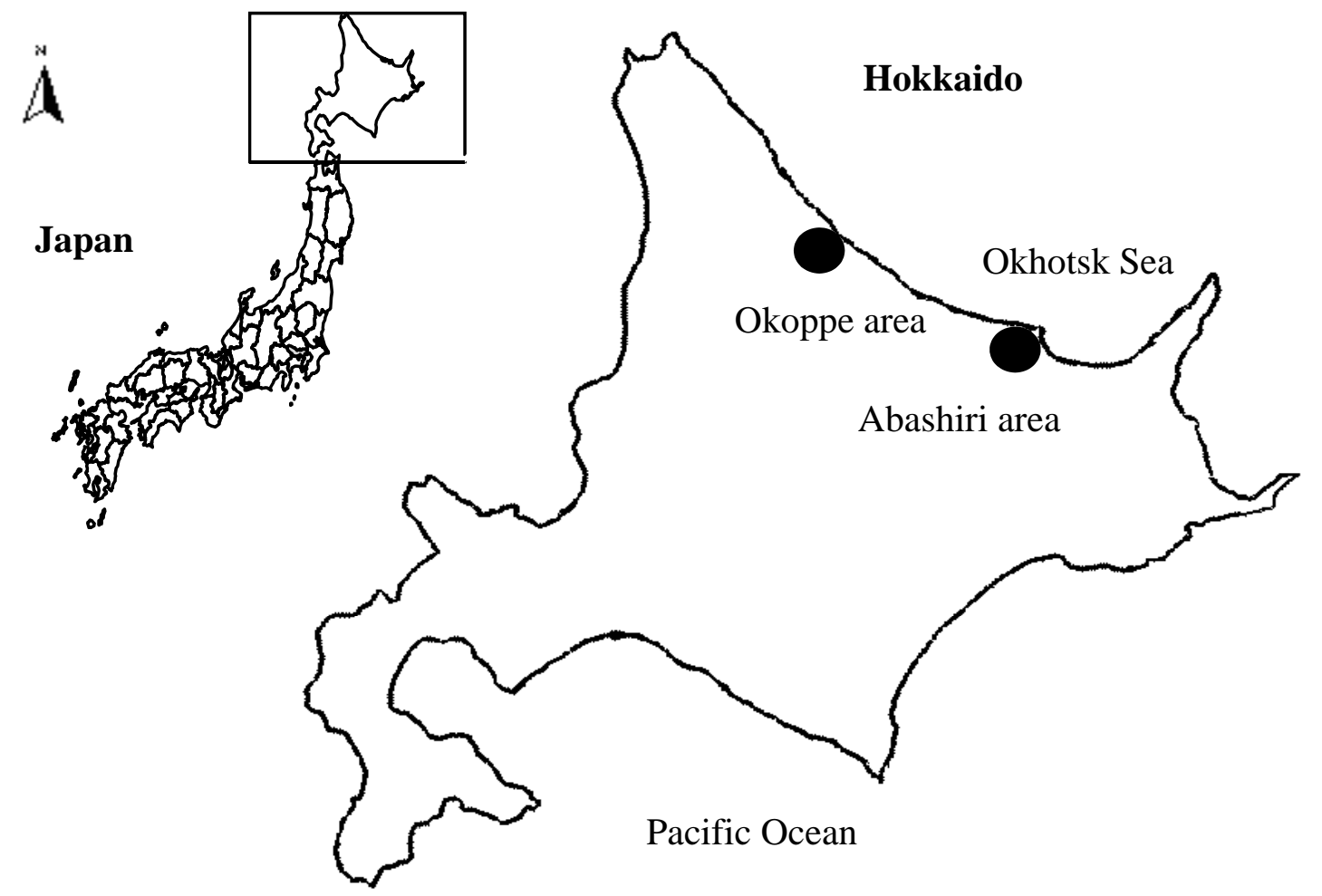

Figure 1. Locations of the study areas in eastern Hokkaido, Japan. 


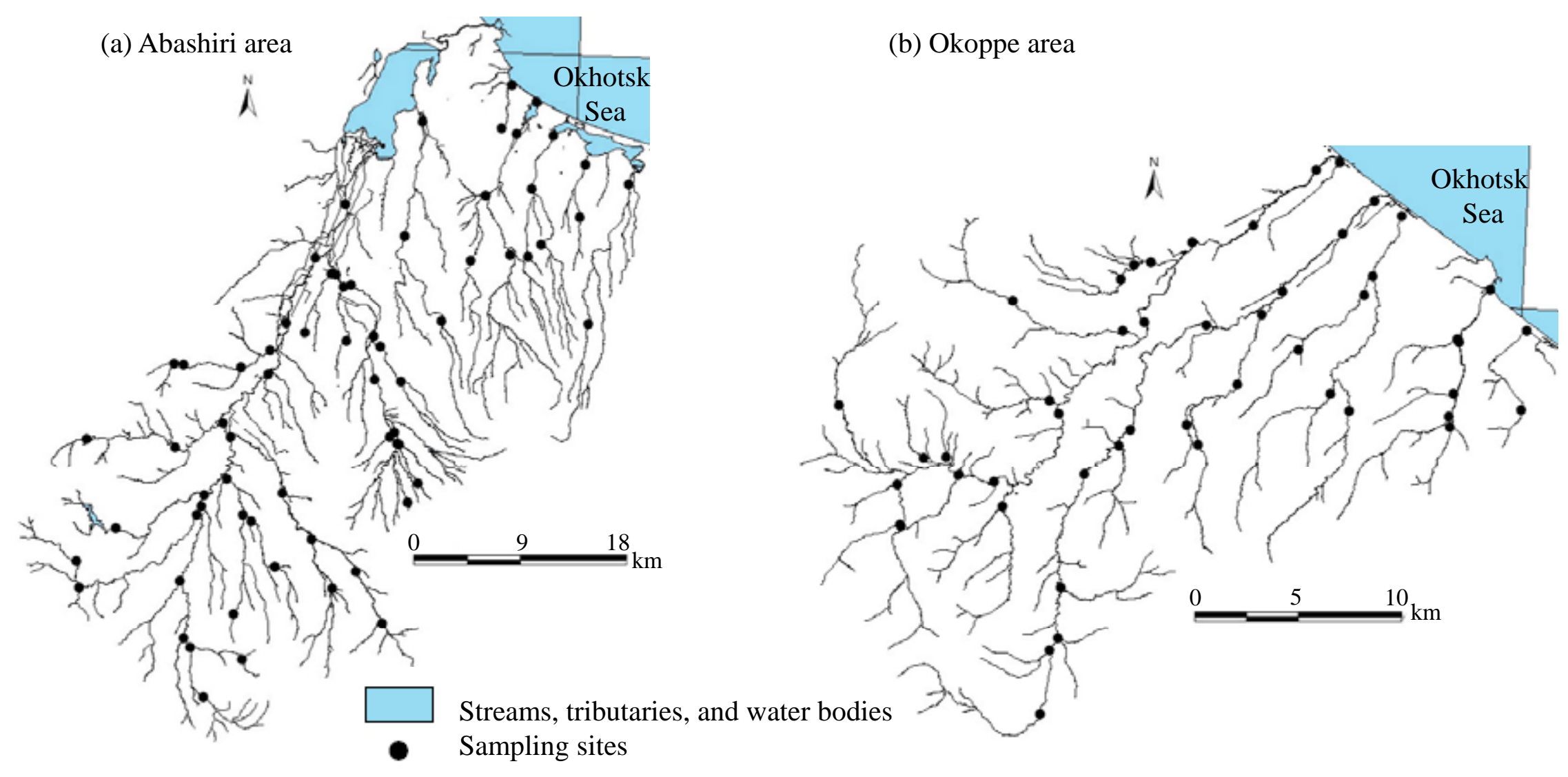

Figure 2. River systems and sampling site distributions in the (a) Abashiri and (b) Okoppe areas. 


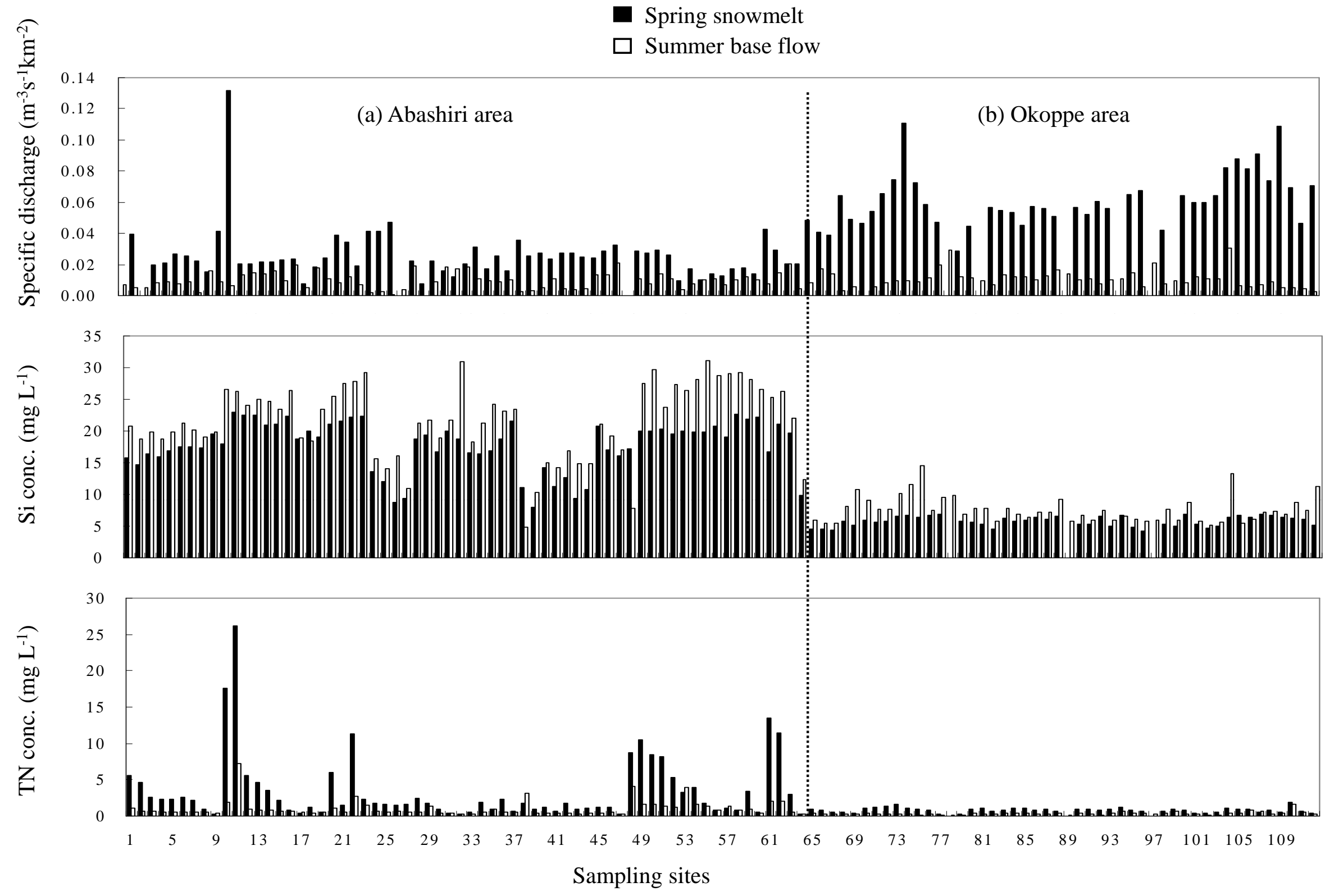

Figure 3. Specific discharge and concentrations of TN and Si in river water during spring snowmelt and summer base flow periods in the (a) Abashiri and (b) Okoppe areas. 

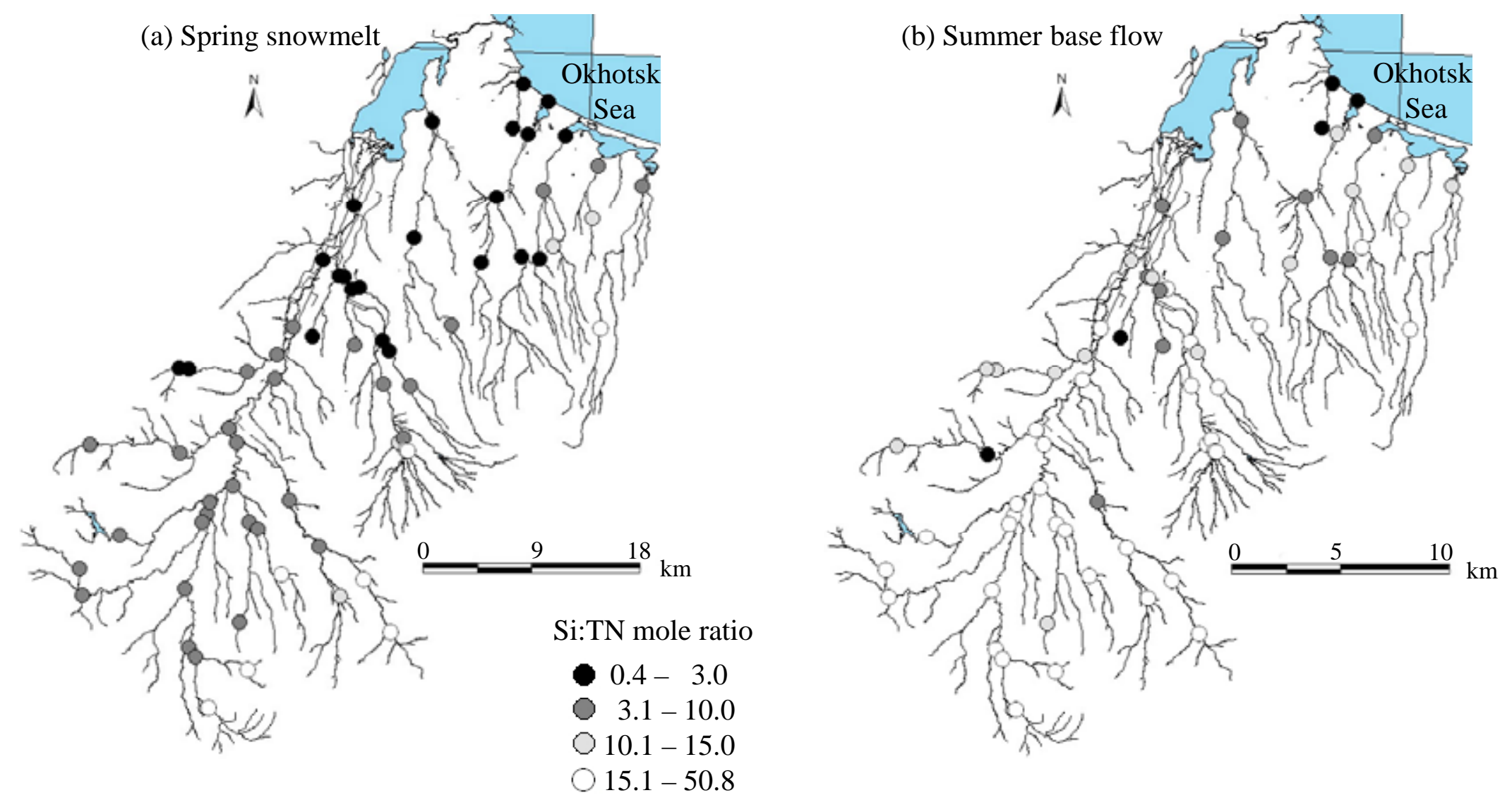

Figure 4. Mole ratio of Si:TN at each sampling site in the Abashiri area during (a) spring snowmelt and (b) summer base flow. 
(a) Spring snowmelt

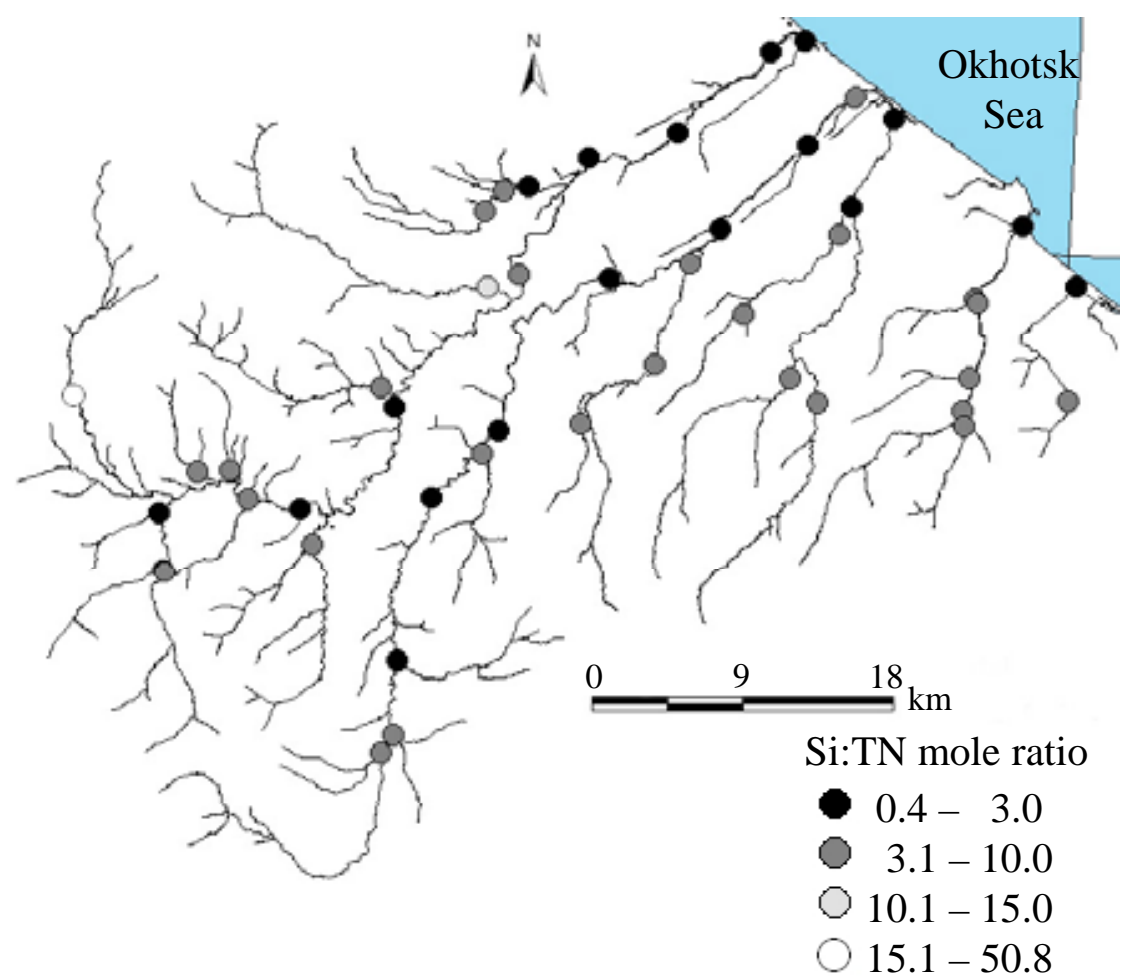

(b) Summer base flow

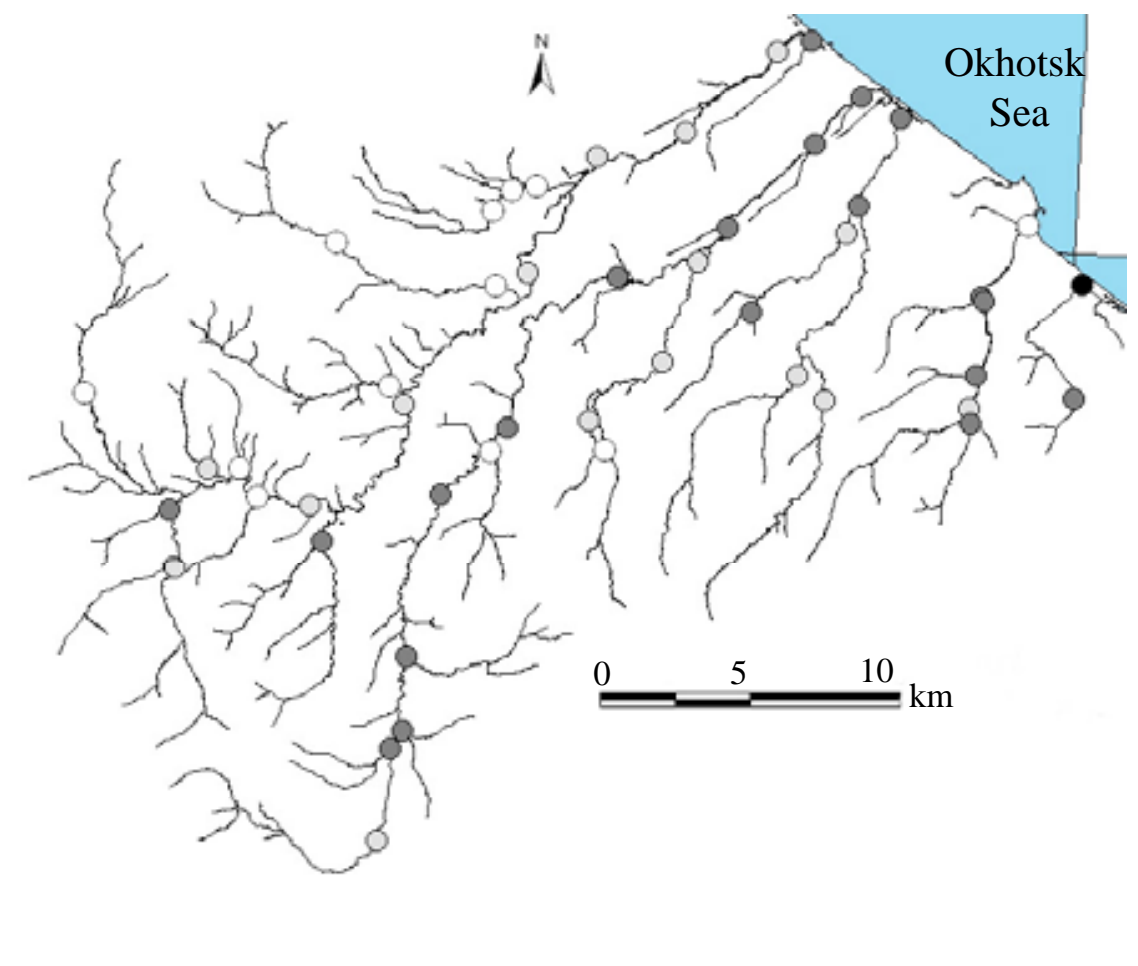

Figure 5. Mole ratio of Si:TN at each sampling site in the Okoppe area during (a) spring snowmelt and (b) summer base flow. 


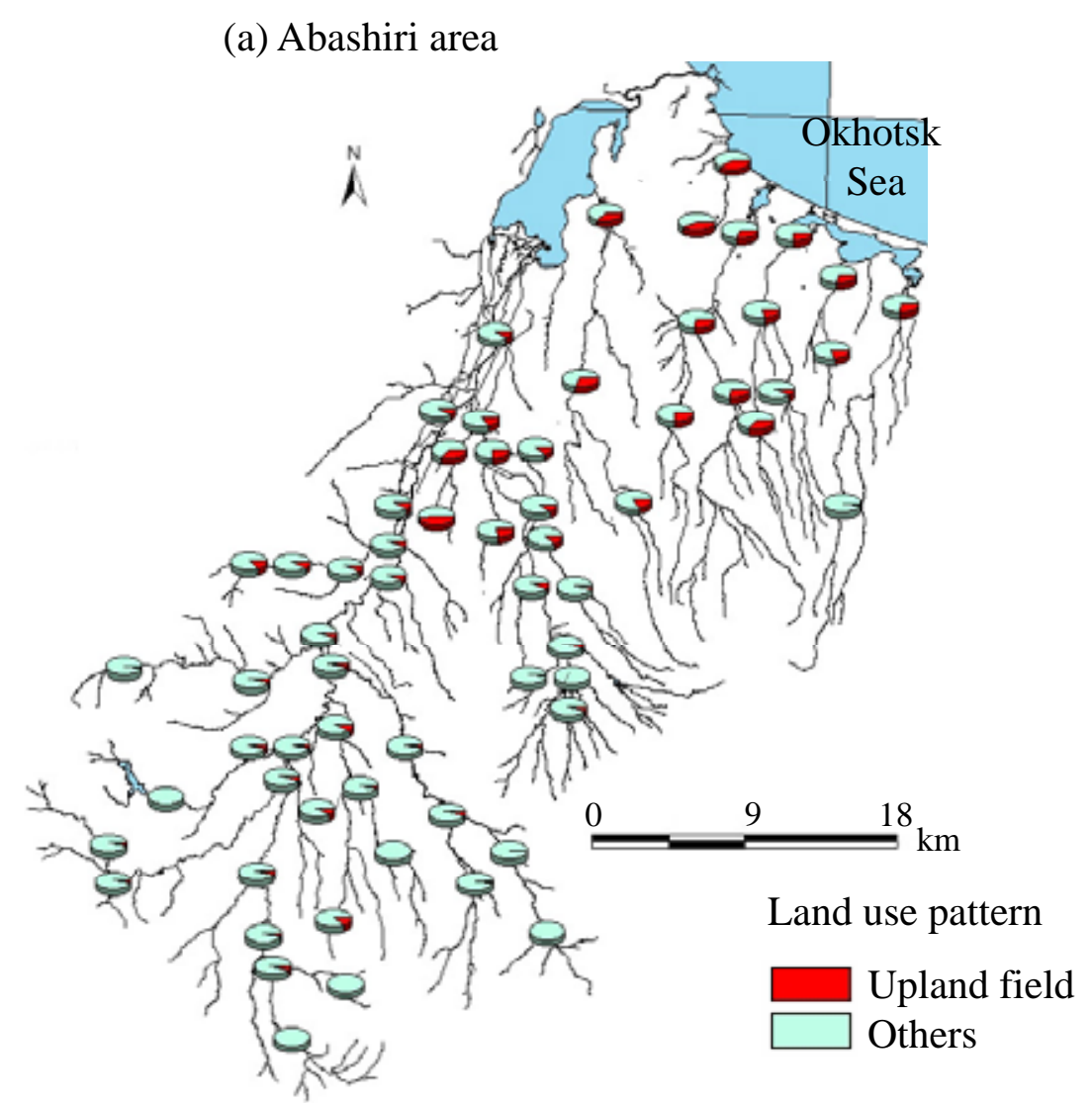

(b) Okoppe area

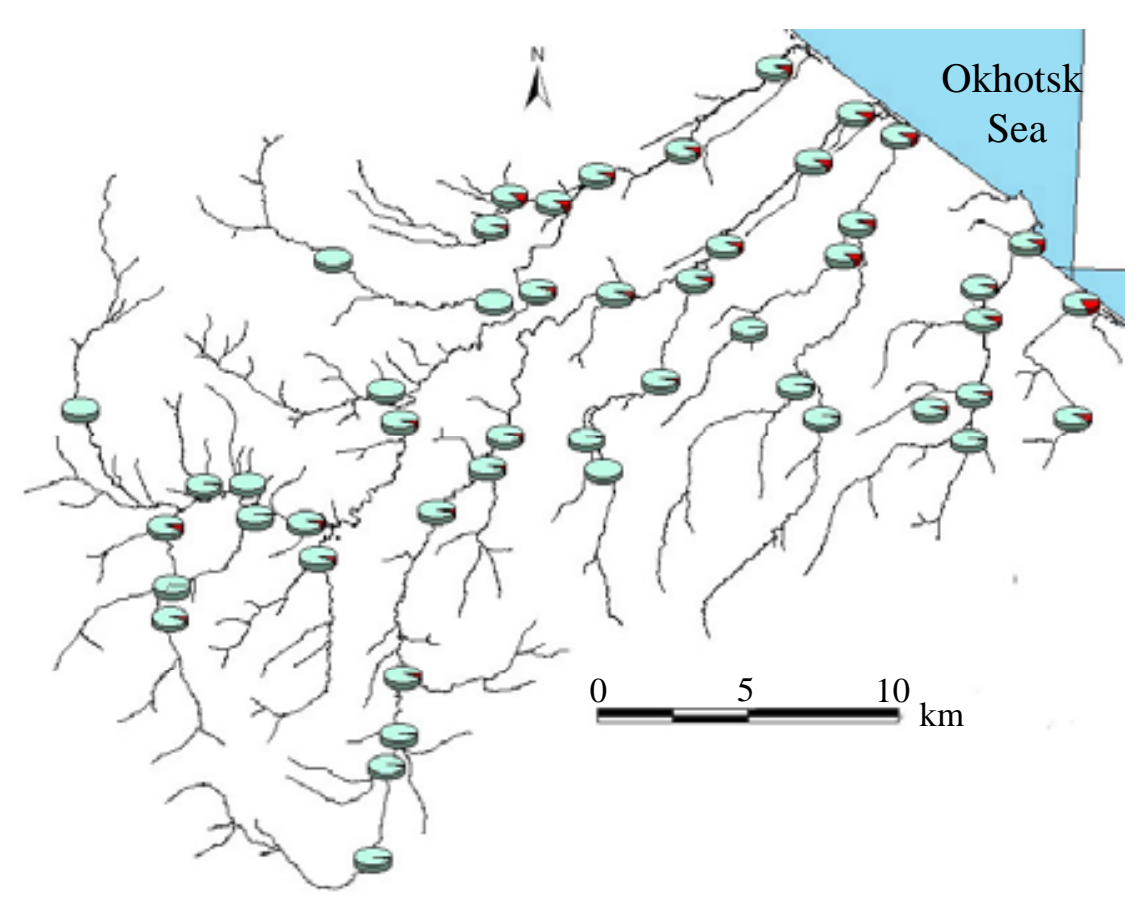

Figure 6. Proportions of upland field in subcatchments in the (a) Abashiri and (b) Okoppe areas. 


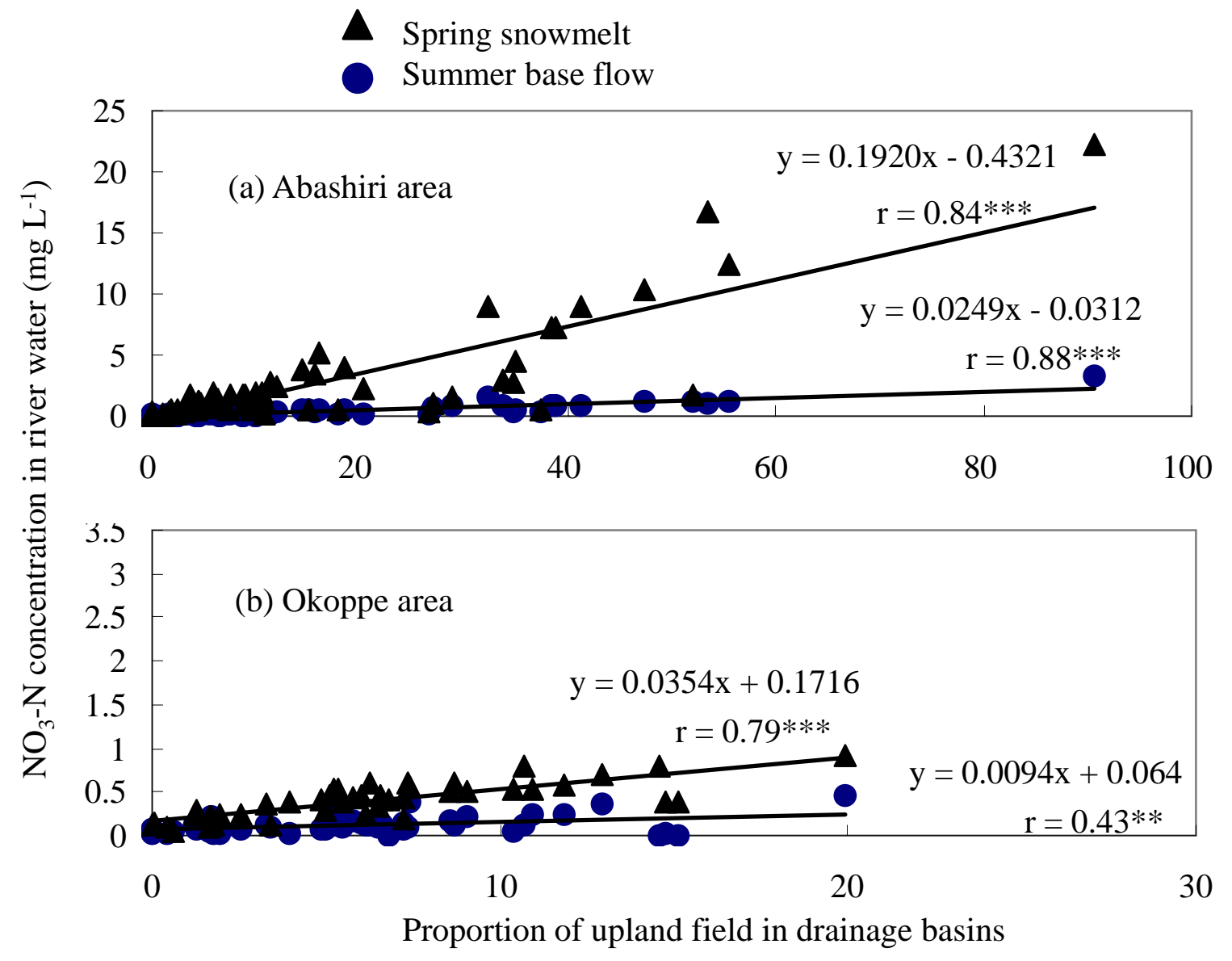

Figure 7. Relationships between proportion of upland fields in catchments and the $\mathrm{NO}_{3}-\mathrm{N}$ concentration in river water for the (a) Abashiri and (b) Okoppe areas. 